Електронне наукове фахове видання з економічних наук “Modern Economics», №18 (2019), 49-54 https://modecon.mnau.edu.ua | ISSN 2521-6392

Удк 334.722.05(477)

DOI: https://doi.org/10.31521/modecon.V18(2019)-08

Іваницька С. Б., кандидат економічних наук, доцент, доцент кафедри економіки, підприємництва та маркетингу, Національний університет «Полтавська політехніка імені Юрія Кондратюка», м. Полтава, Україна

ORCID ID: 0000-0002-7111-270X

e-mail: azz123z@meta.ua

Троян Ю. Т., студентка, Національний університет «Полтавська політехніка імені Юрія Кондратюка», м. Полтава, Україна

ORCID ID: 0000-0003-4617-5415

e-mail: leria.zvezda@gmail.com

\title{
Перспективи розвитку малого та середнього підприємництва в Україні
}

Анотація. У статті досліджено проблеми та перспективи розвитку малого і середнього підприємництва в Україні. Проаналізовано основні напрями державної підтримки малого та середнього підприємництва як в Україні, так і в інших країнах. Виявлено перешкоди, які стримують розвиток підприємництва, серед яких: обмежений доступ до фінансування, обтяжливе законодавство та труднощі у виході на нові ринки. Визначено, що покращенню стану малого та середнього підприємництва в Україні сприяє низка ініціатив і програм підтримки та розвитку з боку Європейського Союзу. Така допомога спрямована на поліпшення бізнес-клімату в країні. Програми полегшують можливість отримання фінансування для малого і середнього бізнесу, надають консультаційну допомогу та адресну підтримку підприємствам. Визначено основні стратегічні цілі розвитку малого і середнього підприємнищтва та завдання, які потрібно вирішити для досягнення поставлених цілей.

Ключові слова: підприємництво; інфраструктура; фінансування; кредитування; інвестиції; навчання; розвиток; конкурентоспроможність.

Ivanytska S., PhD (Economics), Associate Professor of the Department of Economics, Entrepreneurship and Marketing, National University «Yuri Kondratyuk Poltava Polytechnic», Poltava, Ukraine

Troyan Yu., student, National University «Yuri Kondratyuk Poltava Polytechnic», Poltava, Ukraine

\section{Prospects of Small and Medium Business Development in Ukraine}

Annotation. Introduction. Small and medium-sized enterprises are an integral part of the modern market economy. This gives the economy of any country some flexibility, influences its economic growth, mobilizes financial and production resources of the population, accumulates a powerful antitrust potential, plays a system-forming function. Entrepreneurship is a serious factor in solving pressing social and economic problems.

Purpose. The purpose of the article is to summarize the fundamental principles for the support and development of small and medium-sized enterprises in the transition economy. The aim is to develop methodological foundations for improving their efficiency in Ukraine.

Results. It is established that the main reasons for slowing down the development of small and medium-sized enterprises in Ukraine are the lack of an effective mechanism for implementation of state policy for support of small and medium-sized enterprises, the lack of appropriate regulatory support for business development, limited financial resources, limited information and advisory support, imperfection of the training system and further training. The article analyzes the main directions of state support for small and medium-sized enterprises in Ukraine and other countries. Obstacles hindering the development of entrepreneurship have been identified. Such obstacles include limited access to finance, burdensome legislation, and difficulties in entering new markets, etc. These programs are aimed at making breakthroughs and inventions; promote entry into new markets; facilitates the opportunity to obtain financing for business, offer a large amount of investment, grants and vouchers are provided, advisory assistance and targeted support are provided.

Conclusions. The tasks that need to be solved to realize the strategic goals of the development of small and medium businesses in Ukraine are identified. The main ones are the creation of favorable financial conditions for starting and conducting business activities; development and implementation of a special program of support for promising companies and entrepreneurs; creation and development of business support infrastructure; development of competition; support in the social sphere; stimulating demand for enterprise products; creation of conditions for increase of labor productivity; development of micro-credit; implementation of financial support programs; simplification of procedures for access of small and medium-sized enterprises to the use of real estate objects; training, training, and retraining of professional staff for small and medium businesses; provision of state support for small and medium-sized enterprises active in the field of investment activity; conducting information-analytical monitoring of small and medium-sized business development and development of state policy measures for the further development of entrepreneurship.

Keywords: entrepreneurship; infrastructure; financing; lending; investment; training; development; competitiveness.

JEL Classification: M 21.

Стаття надійшла до редакції: 16.11 .2019

Received: 16 November 2019 
Постановка проблеми. Невіддільною складовою сучасного ринкового господарства є мале та середнє підприємництво, яке надає економіці будь-якої країни певну гнучкість, здійснює вплив на ії економічне зростання, мобілізує фінансові та виробничі ресурси населення, акумулює в собі потужний антимонопольний потенціал, відіграє системоутворюючу функцію, сприяє швидкому насиченню ринку якісними товарами й послугами та слугує серйозним фактором розв'язання актуальних соціально-економічних проблем.

На розвиток малого та середнього підприємництва в Україні негативно впливають проблеми відсутності ефективного механізму реалізації державної політики щодо підтримки малого підприємництва, недосконалості й обтяжливості системи оподаткування, відсутності належного нормативноправового забезпечення, адміністративні перешкоди, неврегульованість питань фінансування та кредитування, зокрема мікрокредитування, практична відсутність державної фінансової допомоги, нерозвиненість інфраструктури підтримки підприємництва та відсутність інформаційно-аналітичного моніторингу розвитку малого і середнього бізнесу. Вирішення цих проблем і створення сприятливих умов для розвитку підприємництва потребує застосування нових методів регулювання економіки.

Аналіз останніх досліджень та публікацій. Вагомий внесок у дослідження проблеми становлення та розвитку малого та середнього підприємництва зробили такі західні та вітчизняні науковці як: В. Амітан, О. Амоша, А. Ачкасов, О. Безверха, С. Бейгул [9], В. Борейко [10], З. Варналій [11], В. Геєц, Т. Говорушко [12], П. Данилишин, М. Долішній, О. Кужель, Г. Онищук, О. Ройтер, В. Семиноженко, О. Тіщенко, О. Тимченко [12], В. Торкатюк, Н. Тимчук, В. Фінагін та інші.

Велика кількість проблем функціонування та розвитку малого та середнього підприємництва в
Україні залишаються нерозв'язаними та потребують подальшого дослідження.

Формулювання цілей дослідження. Метою написання статті $€$ узагальнення основних положень щодо підтримки та розвитку малих та середніх підприємств в сучасних економічних умовах та розроблення методичних засад підвищення ефективності їх функціонування в Україні.

Виклад основного матеріалу. За останні роки в Україні доволі активно розвивається сектор малого та середнього бізнесу, який сприяє утворенню нових робочих місць, збільшенню валового внутрішнього продукту, стимулюванню розвитку конкурентоспроможності та інноваційного потенціалу економіки.

Мале підприємництво є закономірно визначеною складовою об'єктивного процесу формування економічної системи як на загальнодержавному, так i регіональному рівнях в Україні. Мале підприємництво $\epsilon$ системоутворювальним фактором формування ринкових відносин у суспільстві [9].

Кількість малих і середніх підприємств в Україні з кожним роком зменшується, що $\epsilon$ негативною тенденцією. Всі інструменти державної політики мають бути спрямовані на стимулювання людей сміливо займатись малим та середнім бізнесом та, відповідно, на створення умов для легкого його ведення.

Державна підтримка малого та середнього підприємництва - це комплекс заходів держави, які спрямовані на створення сприятливих умов для ведення підприємницької діяльності за допомогою податкової, фінансово-кредитної, інноваційної, інвестиційної, кадрової політики тощо.

Державна підтримка малого та середнього підприємництва в Україні повинна здійснюється за такими основними напрямами (рис. 1). створення дієвої інфраструктури підтримки малого та середнього підприємництва

встановлення системи пільг для суб'єктів малого та середнього підприємництва

залучення суб'єктів малого та середнього підприємництва до участі у грантових програмах

забезпечення суб'єктів малого та середнього підприємництва виробничими площами та обладнанням

постачання продукції для державних та регіональних потреб організація підготовки та перепідготовки кадрів для малого та середнього підприємництва

спрощення системи оподаткування, бухгалтерського обліку та фінансової звітності

інформування громадськості щодо умов започаткування та ведення власної справи

запровадження сучасних кредитно-інвестиційних механізмів розвитку підприємництва

створення консультаційних центрів з питань управління якістю на малих та середніх підприємствах

впровадження програм страхування ризиків суб'єктів малого та середнього підприємництва

Рисунок 1 - Основні напрями державної підтримки малого та середнього підприємництва в Україні 
Більшість компаній в Україні є малими та середніми підприємствами. Вони забезпечують роботою понад 4 млн людей та виробляють близько $20 \%$ валового внутрішнього продукту країни. Бізнес-середовище в Україні значною мірою регламентоване, але стандарти та послуги підтримки для малого та середнього підприємництва, політика щодо інновацій та надання допомоги жінкам-підприємцям потребують вдосконалення.

Підтримка малого і середнього підприємництва в Україні на державному рівні полягає в: наданні фінансових продуктів та програм допомоги з боку державних банків, залученні безробітних до організації підприємницької діяльності, підтримці агропромислового комплексу.

На нашу думку, на підтримку та розвиток малого та середнього підприємництва 3 державного бюджету виділяється недостатній обсяг фінансових ресурсів. Підтримка з боку держави існує, але постійні зміни в політиці та законодавстві вносять нестабільність в економічне середовище, тим самим збільшуючи ризики ведення бізнесу та призводячи до банкрутства багато підприємств.

Створення збалансованого середовища щодо підтримки та розвитку малого та середнього підприємництва в Україні можливе лише за умов існування єдиної загальнодержавної економічної політики.

У більшості розвинених країн влада підтримує мале та середнє підприємництво, надаючи їм державні гарантії, субсидії, пільгові кредити, податкові пільги, консультаційні послуги, інші преференції.

Економічно розвинуті держави підтримують малий та середній бізнес як грошима, так і різноманітними пільгами у сфері податкової політики. Податкова політика держави є стимулюючим фактором у його розвитку, суть якого полягає в поступовому зменшенні ставок податків у залежності від розмірів підприємства і зниженні прогресивності оподатковування.

Потужна державна підтримка малого бізнесу існує майже в усіх країнах з розвиненою ринковою економікою. Наприклад, у Німеччині субсидії для малого бізнесу складають близько 4 млрд євро щорічно.

Німеччина запустила 200 програм під загальною назвою «Mittelstand» для підтримки малого i середнього бізнесу, які передбачають виділення 15,5 млрд євро щорічно на кредитування таких підприємств.

Достатньо уваги малому і середньому підприємництву приділяється в США, де діють пільгові ставки податку на доходи до 16 тис. доларів США. Надаються прямі і гарантовані позики. У конгресі США два комітети зайняті проблемами малого та середнього бізнесу. Вже понад 60 років існує U.S. Small Business Administration, яка надає фінансову та консультативну підтримку та виступає гарантом перед кредиторами.
Уряд Японії виділяє субсидії для розвитку суб'єктів малого підприємництва, які беруть активну участь у розвитку наукомісткої і високотехнологічної промисловості. Держава виділяє для них позики та надає допомогу в отриманні кредитів шляхом надання кредитних гарантій. При державній підтримці здійснюється навчання фахівців в спеціально створених центрах і надається кваліфіковане консультування підприємців.

Мале підприємництво в Японії також знаходить підтримку з боку адміністрації префектур, місцевих управлінь зовнішньої торгівлі та промисловості, торгово-промислових палат.

Досить цікава практика розвитку малого та середнього бізнесу в Польщі та Ізраїлі. У цих країнах Урядом створюються державні венчурні фонди, які вкладають кошти в різноманітні стартапи.

Країни Європейського союзу реалізують велику кількість національних та регіональних програм розвитку малого та середнього підприємництва, за якими вони кредитуються на десятки мільярдів євро щорічно.

Покращенню стану малого та середнього підприємництва в Україні сприяє низка ініціатив та програм підтримки з боку іноземних держав. Така допомога спрямована на поліпшення бізнес-клімату в країні. Програми полегшують можливість отримання фінансування для малого і середнього бізнесу, надають консультаційну допомогу та адресну підтримку підприємствам. Також вони отримують технічну підтримку, що дозволяє їм збільшувати експорт та мати вигоду від угоди про вільну торгівлю між Україною та країнами ЄС.

Проєкти та програми Європейського Союзу щодо підтримки та розвитку малого і середнього підприємництва в Україні представлені в таблиці 1.

Як видно з табл. 1, підтримка з боку інших держав $€$ вона здійснюється у вигляді програм та проєктів ЄС по підтримці малого та середнього бізнесу. Ці програми націлені на здійснення проривів та винаходів; сприяють виходу на нові ринки; пропонується великий обсяг інвестицій, надаються гранти та ваучери, консультації, семінари та обмін між учасниками програм.

Отже, підприємництво в Україні має великий потенціал для забезпечення економічного зростання за умови подолання певних перешкод та ефективної реалізації стратегії розвитку малого та середнього підприємництва.

Стратегія розвитку малого та середнього підприємництва розглядається як механізм, який дозволить скоординувати дії органів влади всіх рівнів, представників підприємницької спільноти та організацій інфраструктури підтримки та забезпечити на цій основі відповідність прийнятих очікуванням бізнесу та суспільства в цілому по відношенню до створення сприятливих і комфортних умов для реалізації підприємницького потенціалу громадян. 
Електронне наукове фахове видання з економічних наук "Modern Economics», №18 (2019), 49-54 https://modecon.mnau.edu.ua | ISSN 2521-6392

Таблиця 1 - Проєкти та програми країн Європейського Союзу щодо підтримки та розвитку малого і середнього підприємництва в Україні

\begin{tabular}{|c|c|}
\hline Назва & Мета та учасники \\
\hline $\begin{array}{l}\text { Competiveness of Small and } \\
\text { Medium Enterprises (COSME) - } \\
\text { європейська програма } \\
\text { підтримки малого та } \\
\text { середнього бізнесу }\end{array}$ & $\begin{array}{l}\text { Поліпшення доступу до ринків, зокрема всередині ЄС; поліпшення умов для підвищення } \\
\text { конкурентоспроможності та стабільності підприємств ЄС; сприяння розвитку підприємництва та } \\
\text { підприємницької культури. } \\
\text { Учасники: український малий та середній бізнес, громадські організації, установи, агентства } \\
\text { регіонального розвитку, освітні заклади. Будь які українські бізнес-асоціації, профспілки, кластери, } \\
\text { органи державної влади. }\end{array}$ \\
\hline $\begin{array}{l}\text { Європейська програма } \\
\text { обміну для підприємців } \\
\text { «Erasmus for Young } \\
\text { Entrepreneurs» }\end{array}$ & $\begin{array}{l}\text { Erasmus for Young Entrepreneurs пропонує молодим підприємцям пройти стажування в успішних } \\
\text { європейських компаніях та отримати корисні навички для започаткування та успішного ведення } \\
\text { власного бізнесу в Європі. } \\
\text { Учасники: молоді підприємці, які щойно розпочали власний бізнес або збираються розпочати справу, } \\
\text { досвідчені підприємці (малий та середній бізнес). }\end{array}$ \\
\hline $\begin{array}{l}\text { Програма п } \\
\text { управлінськ } \\
\text { GmbH. «Fit } f \\
\text { with Germar }\end{array}$ & $\begin{array}{l}\text { Грантова програма передбачає стажування представників підприємств у Німеччині } 3 \text { метою } \\
\text { підвищення рівня кваліфікації. } \\
\text { Учасники: молоді керівники середньої та вищої ланки підприємств з експортно-імпортним } \\
\text { потенціалом. }\end{array}$ \\
\hline товний & $\begin{array}{l}\text { Грантова програма полягає у річному супроводі зростання бізнесу: допомога у формуванні чіткої } \\
\text { бізнес-моделі, допомога збуту товарів та послуг, консультаційна допомога з ведення бізнесу. } \\
\text { Учасники: представники малого та середнього бізнесу }\end{array}$ \\
\hline $\begin{array}{l}\text { USAID: програм } \\
\text { українським агр }\end{array}$ & $\begin{array}{l}\text { Підвищення конкурентоспроможності аграрних виробників та створення сприятливого бізнес- } \\
\text { середовища в аграрному секторі; збільшення обсягу інвестицій, підвищення продуктивності, рівня } \\
\text { зайнятості й доходів у аграрному секторі; покращання добробуту сільських громад і вразливих } \\
\text { категорій виробників. } \\
\text { Учасники: малі та середні підприємства. }\end{array}$ \\
\hline & $\begin{array}{l}\text { Надає фінансування, підтримку та навчання малим підприємствам. } \\
\text { Учасники: малі та середні підприємства. }\end{array}$ \\
\hline $\begin{array}{l}\text { Програма «Initiative East» в } \\
\text { рамках ПВЗВТ }\end{array}$ & $\begin{array}{l}\text { Розширення доступу до фінансування у вигляді поліпшених умов кредитування; підтримка } \\
\text { мікрофінансових установ у забезпеченні фінансування для мікропідприємств; надання адресної } \\
\text { фінансової та технічної допомоги пріоритетним виробничо-збутовим мережам в агрохарчовій галузі. } \\
\text { Учасники: малі та середні підприємства. }\end{array}$ \\
\hline $\begin{array}{l}\text { малого } \\
\text { і від } \\
\text { банку } \\
\text { розвитку }\end{array}$ & $\begin{array}{l}\text { ЄБРР пропонує гранти малим та середнім підприємствам для зростання їх бізнесу. Допомагає } \\
\text { підприємствам залучати висококваліфікованих консультантів, які здатні якісно трансформувати їх } \\
\text { бізнес і надає гранти для часткової оплати послуг консультантів. } \\
\text { Учасники: штат - від } 10 \text { до } 250 \text { працівників. Період діяльності не менше 2-х років. }\end{array}$ \\
\hline & $\begin{array}{l}\text { Надає консультаційну допомогу спеціалістам з метою підтримки малих та середніх підприємств, } \\
\text { органів комунального управління, економічних об'єднань, соціальних та медичних закладів, а також } \\
\text { шкільних та професійних освітніх закладів. } \\
\text { Учасники: підприємства, установи та організації різних форм власності; фізичні особи - підприємці; } \\
\text { навчальні заклади; органи місцевого самоврядування; медичні заклади; заклади культури та } \\
\text { мистецтва; неурядові громадські організації та фонди, тощо. }\end{array}$ \\
\hline $\begin{array}{l}\text { Програма Інноваційних } \\
\text { ваучерів ЄБРР }\end{array}$ & $\begin{array}{l}\text { Підтримка українських компаній, покращення умов для розвитку та впровадження кліматичних } \\
\text { технологій. } \\
\text { Учасники: українські компанії. }\end{array}$ \\
\hline \multicolumn{2}{|c|}{ Підтримка фінансування малих та середніх підприємств України в рамках програм Німецько-українського фонду (НУФ) } \\
\hline Програма мікрокредитування & $\begin{array}{l}\text { Фінансування виробництва, сфери послуг, сільського господарства, торгівлі (тільки для ФОП та } \\
\text { мікропідприємств). } \\
\text { Учасники: фізичні особи-підприємці, мікропідприємства (не більш ніж } 20 \text { постійних працівників), малі } \\
\text { підприємства (не більш ніж } 250 \text { постійних працівників), середні підприємства (не більш ніж } 500 \\
\text { постійних працівників) }\end{array}$ \\
\hline $\begin{array}{l}\text { Програма з рефінансування } \\
\text { заходів підтримки системи } \\
\text { кредитування у сільській } \\
\text { місцевості }\end{array}$ & $\begin{array}{l}\text { Програма розрахована на розширення кредитування ММСП у сільській місцевості, тобто населених } \\
\text { пунктах, чисельність населення яких не перевищує } 100 \text { тис. мешканців. Фінансування виробництва, } \\
\text { сфери послуг, сільського господарства, торгівлі (тільки для ФОП та мікропідприємств). } \\
\text { Учасники: ФОП та приватні малі і середні підприємства, які мають не більше ніж } 250 \text { постійних } \\
\text { працівників та обсяг валового доходу від реалізації продукції (робіт, послуг) не більше ніж еквівалент } \\
5 \text { млн євро }\end{array}$ \\
\hline $\begin{array}{l}\text { Програма з кредитування } \\
\text { ММСП України за } \\
\text { пріоритетними галузевими } \\
\text { напрямами }\end{array}$ & $\begin{array}{l}\text { Ця програма пропонує пільгові умови кредитування підприємств, які працюють в окремиих галузях, що } \\
\text { розглядаються НУФ як пріоритетні та стратегічно важливі. } \\
\text { Учасники: ФОП та приватні малі і середні підприємства, які мають не більше ніж } 250 \text { постійних } \\
\text { працівників та обсяг валового доходу від реалізації продукції (робіт, послуг) не більше ніж еквівалент } \\
5 \text { млн євро }\end{array}$ \\
\hline $\begin{array}{c}\text { Програма з підтримки } \\
\text { фінансування інвестиційних } \\
\text { проєктів малих та середніх } \\
\text { підприємств за } \\
\text { пріоритетними напрямами }\end{array}$ & $\begin{array}{l}\text { Програма розроблена з метою фінансування інвестицій в основний та обіговий капітал малих та } \\
\text { середніх підприємств. } \\
\text { Учасники: фізичні особи-підприємці, мікропідприємства (не більш ніж } 20 \text { постійних працівників), малі } \\
\text { підприємства (не більш ніж } 250 \text { постійних працівників), середні підприємства (не більш ніж } 500 \\
\text { постійних працівників) }\end{array}$ \\
\hline
\end{tabular}

Джерело: побудовано авторами на основі [13] 
Місія стратегії розвитку малого та середнього підприємництва - створення конкурентоспроможної, гнучкою економіки, яка забезпечуватиме високий рівень індивідуалізації товарів і послуг, високу швидкість технологічного оновлення і стабільну зайнятість, а також буде основою для стійкого підвищення якості життя населення шляхом розвитку сфери підприємництва.

Метою стратегії $\epsilon$ розвиток сфери малого і середнього підприємництва як одного з факторів, 3 однієї сторони, інноваційного розвитку і поліпшення галузевої структури економіки, а з іншого боку, соціального розвитку та забезпечення стабільно високого рівня зайнятості.

Стратегічними цілями розвитку малого і середнього бізнесу в Україні є: поповнення бюджету за рахунок податкових надходжень, реалізація підприємницького потенціалу населення, створення нових робочих місць, зниження рівня безробіття, зростання конкурентоспроможності бізнесу.

Висновки. Отже, з метою реалізації поставлених стратегічних цілей розвитку малого і середнього підприємництва в Україні потрібно вирішити такі першочергові завдання:

- створення сприятливих фінансових передумов для започаткування та провадження підприємницької діяльності, доступності фінансових ресурсів для суб'єктів підприємницької діяльності;

- розроблення та реалізація спеціальної програми підтримки перспективних компаній і підприємців;

- створення та розвиток об'єктів інфраструктури підтримки суб'єктів малого і середнього підприємництва (в тому числі міжрегіональних);

- розвиток конкуренції на локальних ринках;

- підтримка підприємництва в соціальній сфері;

- розширення доступу малих та середніх підприємств до закупівель для муніципальних та державних потреб, а також для потреб підприємств 3 державною участю;
- стимулювання попиту на продукцію малих і середніх підприємств на основі підвищення її якості;

- сприяння в просуванні продукції малих і середніх підприємств на регіональний, державний та міжнародний ринки;

- створення умов для підвищення продуктивності праці на малих і середніх підприємствах;

- вдосконалення нормативно-правової бази, що регулює підприємницьку діяльність;

- розвиток кредитно-фінансових механізмів та впровадження фінансових технологій, спрямованих на розвиток підприємництва;

- розвиток мікрокредитування;

- реалізація програм фінансової підтримки, в рамках яких підприємці матимуть можливість отримувати субсидію для відшкодування витрат на ведення бізнесу, гранти, мікропозики, гарантію по кредиту або кредит на пільгових умовах;

- спрощення процедур доступу малих і середніх підприємств до використання об'єктів нерухомого майна;

- навчання, підготовка і перепідготовка професійних кадрів для малого і середнього бізнесу;

- розкриття підприємницького потенціалу;

- розвиток малого інноваційного бізнесу;

- забезпечення державної підтримки суб'єктів малого та середнього підприємництва, які працюють в сфері інвестиційної діяльності;

- проведення інформаційно-аналітичного моніторингу розвитку малого і середнього бізнесу та розробка заходів державної політики щодо подальшого розвитку підприємництва;

- підтримка нових механізмів співпраці органів виконавчої влади та громадськості.

Таким чином, малі та середні підприємства мають великий потенціал для створення нових робочих місць та прискорення економічного зростання в країні, але існуючі на даний час перешкоди стримують їхній розвиток.

\section{Література:}

1. Belas J., Bilan Y., Demjan V., Sipko J. Entrepreneurship in SME segment: case study from the Czech Republic and Slovakia. Amfiteatru Economic. 2015. Vol. 17(38). pp. 308-326.

2. Lew Sook Ling. Impacts of Information Technology Capabilities on Small and Medium Enterprises (SMEs) and Large Enterprises. Journal of Innovation Management in Small and Medium Enterprise. 2017. DOI:10.5171/2017.133143.

3. Kotane I., Kuzmina-Merlino I. Analysis of Small and Medium Sized Enterprises' Business Performance Evaluation Practice at Transportation and Storage Services Sector in Latvia. Procedia Engineering. 2017. Vol. 178. pp. $182-191$. doi:10.1016/j.proeng.2017.01.093.

4. Sousa S. D., Aspinwall E. M., Rodrigues A. G. Performance measures in English small and medium enterprises: survey results. Benchmarking: An International Journal. 2006. Vol. 13 (1/2). pp. 120-134. http://dx.doi.org/10.1108/14635770610644628.

5. Poufinas T., Galanos G., Papadimitriou P. The Competitiveness of Small and Medium Enterprises in Adverse Economic Environments. Theoretical Economics Letters. 2018. Vol. 8. pp. 2788-2802. doi:10.4236/tel.2018.813175.

6. Lisowska R., Stanislawski R. The Cooperation of Small and Medium-Sized Enterprises with Business Institutions in the Context of Open Innovation. Procedia Economics and Finance. 2015. Vol. 23. pp. 1273-1278. https://doi.org/10.1016/S2212-5671(15)00509-2.

7. Teletov O., Grigorenko V. The state and prospects of marketing strategies for small and medium business enterprises in Ukraine. Innovative technologies and scientific solutions for industries. 2019. Vol. 2 (8). pp. 97-104. DOI:https://doi.org/10.30837/25229818.2019.8.097.

8. Ruchkina G., Melnichuk M., Frumina S., Mentel G. Small and medium enterprises in regional development and innovations. Journal of International Studies. 2017. Vol. 10(4). pp. 259-271. doi:10.14254/2071-8330.2017/10-4/20. 
9. Бейгул С. Б. Основи формування регіональної політики розвитку малого підприємництва: дис. канд. екон. наук: 08.10 .01 / Полтавський національний технічний ун-т ім. Юрія Кондратюка. Полтава, 2006. 240 с.

10. Борейко В. Управління розвитком малого та середнього бізнесу в Україні. Intercultural Communication. 2018. № 4 (1), c. $229-244$.

11. Варналій 3. С. Мале підприємництво: основи теорії і практики. Київ : Знання, 2001. 277 с.

12. Говорушко Т. А. Малий бізнес : навч. посібник. Київ : Центр навчальної літератури, 2006. 200 с.

13. Агенція регіонального розвитку Житомирської області: веб-сайт. URL: http://zrda.org/(дата звернення: 15.09.2019).

\section{References:}

1. Belas, J., Bilan, Y., Demjan, V. \& Sipko, J. (2015). Entrepreneurship in SME segment: case study from the Czech Republic and Slovakia. Amfiteatru Economic, 17(38), 308-326.

2. Lew Sook Ling (2017). Impacts of Information Technology Capabilities on Small and Medium Enterprises (SMEs) and Large Enterprises. Journal of Innovation Management in Small and Medium Enterprise, 2017 (2017), DOI:10.5171/2017.133143.

3. Kotane, I. \& Kuzmina-Merlino, I. (2017). Analysis of Small and Medium Sized Enterprises' Business Performance Evaluation Practice at Transportation and Storage Services Sector in Latvia. Procedia Engineering, 178, $182-191$. doi:10.1016/j.proeng.2017.01.093.

4. Sousa, S.D., Aspinwall, E.M. \& Rodrigues, A.G. (2006). Performance measures in English small and medium enterprises: survey results. Benchmarking: An International Journal, 13 (1/2), 120-134. http://dx.doi.org/10.1108/14635770610644628.

5. Poufinas, T., Galanos, G. \& Papadimitriou, P. (2018). The Competitiveness of Small and Medium Enterprises in Adverse Economic Environments. Theoretical Economics Letters, 8, 2788-2802. doi:10.4236/tel.2018.813175.

6. Lisowska, R. \& Stanislawski, R. (2015). The Cooperation of Small and Medium-Sized Enterprises with Business Institutions in the Context of Open Innovation. Procedia Economics and Finance, 23, 1273-1278. https://doi.org/10.1016/S2212-5671(15)00509-2

7. O. Teletov \& Grigorenko, V. (2019). The state and prospects of marketing strategies for small and medium business enterprises in Ukraine. Innovative technologies and scientific solutions for industries, 2 (8), 97-104. DOI:https://doi.org/10.30837/25229818.2019.8.097 [in Ukrainian].

8. Ruchkina, G., Melnichuk, M., Frumina, S. \& Mentel, G. (2017). Small and medium enterprises in regional development and innovations. Journal of International Studies, 10(4), 259-271. doi:10.14254/2071-8330.2017/10-4/20

9. Bejhul, S. B. (2006). Bases of formation of regional policy of development of small business (Abstract of Ph.D. Thesis). Deployment of productive forces and regional economy. Poltava: Poltava National Technical Yuri Kondratyuk University.

10. Boreiko, V. (2018). Management by the Development of Small and Medium Business in Ukraine. Intercultural Communication, 4(1), 229-244. [in Ukrainian].

11. Varnalij, Z. S. (2010). Male pidpryiemnytstvo: osnovy teorii i praktyky. Kyiv: Znannia [in Ukrainian].

12. Hovorushko, T. A. \& Tymchenko, O. I. (2006). Malyj biznes: navch. posibnyk. Kyiv: Tsentr navchal'noi literatury [in Ukrainian].

13. Zhytomyr Region Development Agency. Official web-site. Retrieved from http://zrda.org/ [in Ukrainian]. 